\title{
Myelopathy and adult T-cell leukemia associated with HTLV-1 in a young patient with hearing loss as the initial manifestation of disease
}

\author{
Mielopatia e leucemia de células T do adulto associada ao HTLV-1 em um \\ paciente jovem com perda auditiva como manifestação inicial da doença
}

\author{
Denise Utsch Gonçalves', Lílian Felipe¹, Anna Bárbara Carneiro-Proietti², \\ Antônio Carlos Guedes ${ }^{3}$, Olindo Assis Martins-Filho ${ }^{4}$ and José Roberto Lambertucci ${ }^{1}$
}

\begin{abstract}
A young male developed hearing loss, vertigo, headache and facial palsy. Neurological examination did not show any abnormalities. Two years later, cervical lymphadenopathy, hepatosplenomegaly and atypical lymphocytes in peripheral blood revealed leukemia. At the same time, acquired ichthyosis was observed. Subsequently, neurological abnormalities revealed myelopathy associated with HTLV-1, due to vertical transmission.
\end{abstract}

Key-words: Leukemia. Myelopathy. Human T cell lymphotropic virus.

\section{RESUMO}

Um jovem do sexo masculino desenvolveu perda auditiva, vertigem, cefaléia e paralisia facial. Exame neurológico sem alterações. Dois anos mais tarde, linfadenopatia cervical, hepatoesplenomegalia e linfócitos atípicos no sangue periférico divulgado leucemia. Concomitante, observou-se ictiose adquirida e, posteriormente, anormalidades neurológicas revelaram mielopatia associada ao HTLV-1, transmitido verticalmente.

Palavras-chaves: Leucemia. Mielopatia. Vírus linfotrópico de células T humanas.

Human T cell lymphotrophic virus type 1 (HTLV-1) is endemic in various parts of the world and has high prevalence rates in South America ${ }^{2}$. In Brazil, the Interdisciplinary HTLV-I/II Research Group (IHRG) has been studying the epidemiological pattern and clinical characteristics of this virus. An open cohort of former candidates for blood donation who were discovered to be infected with HTLV-1 was started by the IHRG in 1997, thereby enabling observations on the natural history of the infection. Patients with diseases related to HTLV-1 have also been evaluated. So far, 890 HTLV-1 individuals have been registered for follow-up.

HTLV-1 is associated with adult T-cell leukemia/lymphoma (ATLL) and myelopathy/tropical spastic paraparesis (HAM/TSP). Simultaneous occurrence of both diseases in one individual is considered to be rare ${ }^{3}$. The prevalence of central nervous system (CNS) involvement in acute ATLL is reported to be around $10 \%$. Considering deafness as a manifestation of ATLL, only one case

\footnotetext{
1. Tropical Medicine Post Graduate Program, Faculty of Medicine, Federal University of Minas Gerais. Belo Horizonte. MG, Brazil. 2. Hemominas Foundation, Minas Gerais State Centre of Hematology and Blood Transfusion. Belo Horizonte. MG, Brazil. 3. Medical Medicine Post Graduate Program, Faculty of Medicine, Federal University of Minas Gerais. Belo Horizonte. MG, Brazil. 4. René Rachou Research Center, The Oswaldo Cruz Foundation - FIOCRUZ. Belo Horizonte. MG, Brazil.

Address to: Dra. Lilian Felipe. Depto de Fonoaudiologia/FM/UFMG. Av. Prof. Alfredo Balena, ${ }^{\circ} 190$, sala 69, 30100-130 Belo Horizonte, MG, Brazil.

Telefax: 5531 3409-9950/9611

e-mail: lilianfelipe@hotmail.com

Received in 17/09/2008

Accepted in 29/04/2009
}

has been reported so far ${ }^{6}$. Here, we report on the case of a young man who developed ATLL and HAM/TSP. We believe that the first ATLL-related manifestations occurred two years before our interventions, when the patient had acute meningitis with involvement of the VII and VIII cranial nerves (vertigo, bilateral deafness and facial palsy).

\section{CASE REPORT}

The IHRG physicians evaluated a 21-year-old Brazilian man with cervical lymphadenopathy and hepatosplenomegaly, at an emergency center. He was deaf and the neurological examination showed stiff gait, increased knee reflexes, weakness in both legs, stiffness of the lower extremities, ankle clonus and extensor plantar responses. Attention was drawn to the dermatological examination, because the patient presented acquired ichthyosis. A hemogram was performed, and it showed a white blood cell count of $21 \times 10 / L$ with $30 \%$ abnormal lymphocytes. HTLV-1 infection was subsequently identified through the presence of antibodies in the blood, normal protein levels $(23 \mathrm{mg} / \mathrm{dl})$, mononuclear cell counts in the cerebrospinal fluid (CSF), positive ELISA and Western Blot (WB) for HTLV-1 antibodies in serum and CSF. This was confirmed by PCR on the blood.

The phenotype of malignant cells present in blood and tissue was that of activated mature CD4+ helper T cells, CD8- and TdT-. Surface marker analysis showed that CSF cells were positive 
for CD4. Southern blotting revealed monoclonal integration of HTLV-I proviral DNA.

The diagnostic criteria for both HAM/TSP ${ }^{9}$ and ATLL ${ }^{32}$ were met. The patient died consequent to fungal sepsis three months later. Regarding the risk factors for HTLV-1 infection, the patient had been breast fed by his mother for one year and she was shown to be an HTLV-1 asymptomatic carrier.

Analysis on the patient's medical records showed that the first complaint relating to hearing loss had occurred two years earlier. At that time, when the patient was 19 years of age, he had been seen in a tertiary hospital because of acute headache, bilateral hearing loss, vertigo and left facial palsy, and examinations were performed as follows. An audiogram showed moderate bilateral perceptive hearing loss. The auditory brain stem response indicated retrolabyrinthine disturbance. Complete blood cell tests revealed: hemoglobin of $11.5 \mathrm{~g} / \mathrm{dL}$, platelet count of $150 \times 10 / \mathrm{L}$, white blood cell count of 18x10/L and typical lymphocyte count of 11.1x10/L. The serum calcium and lactate dehydrogenase concentrations were normal. The plantar reflexes were normal and no dermatological lesions were seen. The patient declared that he had not had any previous transfusion, drug addiction or sexual promiscuity. Nuchal rigidity was the abnormal neurological sign observed. Lumbar puncture and CSF analysis showed cytochemical abnormalities suggestive of lymphocytic meningitis, testing negative for soluble bacterial antigens, with a protein level of $220 \mathrm{mg} / \mathrm{dl}$ and a normal glucose level. No tumor was observed in the brain or the lumbar region using computed tomography (CT) and magnetic resonance imaging (MRI).

Considering the presumptive diagnosis of viral meningitis and the cranial nerve involvement when the patient was 19 years of age, it was decided to administer corticosteroids (prednisone, $1 \mathrm{mg} / \mathrm{kg} /$ body weight) and acyclovir (30mg/kg/body weight), for 10 days. The treatment brought about improvements in the facial palsy, vertigo and headache, but not the hearing loss. Prednisone was progressively withdrawn after 20 days of therapy. The HTLV-1 infection had not been diagnosed at that point in time and the patient was not followed up after hospital discharge.

Two years later, discomfort relating the dermatological lesions and sudden worsening of hearing levels and headache made him look for medical attention again, which was when he was first seen by the IHRG physicians.

\section{DISCUSSION}

Hearing loss is not considered to be a common CNS symptom relating to leukemia ${ }^{6}{ }^{10}$. It is unclear why the auditory nerve was the site of the initial symptom in the present case. The hearing loss might have been caused by infiltration to the auditory nerve of ATLL cells, which might have originated in other lymph nodes and later infiltrated the CNS through the blood-brain barrier ${ }^{6}$. In a retrospective analysis, it is rational to think that aseptic meningitis could be related to HTLV-1 infection, thus allowing ATLL to be considered as the first diagnosis ${ }^{112}$.

The supposition is that the corticosteroid decreased the lymphocytic meningeal infiltration, with temporary control over the hematological disease. Improvement in ATLL-related meningitis through corticosteroid therapy alone has already been described ${ }^{11}$. However, the correlation of high-dose corticosteroid therapy with immune suppression and ATLL development due to proviral load increase has been studied ${ }^{12}{ }^{13}$. This possibility should be considered, bearing in mind the association between ATLL and HAM/TSP development in the present case. Patientswith ATLLarefunctionallyimmunocompromised and may develop various opportunistic infections ${ }^{1}$. Moreover, treatment with steroids may have contributed towards the development of HAM/ TSP, which is directed related to high proviral loads 8 .

The occurrence of HAM/TSP and ATLL in the same patient has been considered to be rare ${ }^{3}$. ATLL is largely associated with breastfeeding, but not HAM/TSP, in which the blood route seems to be more important, with disease development usually in the fifth decade? ${ }^{9}$. The acquired ichthyosis observed in this patient has been associated with HAM/TSP ${ }^{11}$.

In conclusion, HTLV-1 screening should be considered for patients with progressive cranial nerve involvement. The treatment for HTLV1-related diseases with high-dose corticosteroid therapy should take into account the immunosuppression and proviral load increase.

\section{REFERENCES}

1. Bazarbachi A, Ghez D, Lepelletier Y, Nasr R, de Thé H, El-Sabban ME, Hermine 0. New therapeutic approaches for adult T-cell leukaemia. The Lancet Oncoly 5: 664-672, 2004.

2. Carneiro-Proietti ABF, Catalan-Soares B, Proietti FA, GIPH. Human T-cell lymphotropic viruses (HTLV-I/II) in South America: should it be a public health concern? Journal Biomedical Science 9: 587-595, 2002.

3. Furukawa Y, Okadome T, Tara M, Niina K, Izumo S, Osame M. Human T-cell lymphotropic virus type-I (HTLV-I) associated myelopathy/tropical spastic paraparesis with acute type of adult T-cell leukemia. Internal Medicine 34: 1130-1133, 1995.

4. Gonçalves DU, Guedes ACM, Carneiro-Proietti AB. Simultaneous occurrence of mielopathy, uveitis and smouldering adult T cell leukemia. International Journal of STD \& AIDS 10: 336-337, 1999.

5. Gonçalves DU, Guedes AC, Carneiro-Proietti AB, Martins ML, Proietti FA, Lambertucci JR. Dermatologic lesions in asymptomatic blood donors seropositive for human T cell lymphotropic virus type-1. The American Journal of Tropical Medicine and Hygiene 68: 562-565, 2003.

6. Harada Y, Tsunemichi S, Hayashi T. Adult T-cell leukemia/lymphoma with initial deafness. International Journal of Hematology 71: 66-69, 2000.

7. Matsumoto M, Nomura K, Matsumoto T. Adult T-cell leukemia-lymphoma in Kagoshima district, southwestern Japan: clinical and hematological characteristics. Japonese Journal of Clinical Oncology 9: 325-336, 1979.

8. Olindo S, Lezin A, Cabre P, Merle H, Saint-Vil M, Kaptue ME, Césaire R, Smadja D. HTLV-1 proviral load in peripheral blood mononuclear cells quantified in 100 HAM/TSP patients: a marker of disease progression. Journal of Neurological Science 237: 53-59, 2005.

9. Osame M, Igata A, Matsumoro M, Usuku K, Izumo S, Kosaka K. HTLV-1 associated myelopathy: a report of 85 cases. Annals of Neurology. 22: 116-117, 1987.

10. Pochedly C. Neurologic manifestations in acute leukemia: involvement of cranial nerves and hypothalamus. New York State Journal of Medicine 75: 715-721, 1975.

11. Sharata HH, Colvin JH, Fujiwara K. Cutaneous and neurologic disease associated with HTLV-I infection. Journal of American Academy of Dermatology 36: 869-871, 1997.

12. Shimoyama M. Diagnostic criteria and classification of clinical subtypes of adult T-cell leukaemia-lymphoma. British Journal of Haematology 79: 428-443, 1991.

13. Taylor GP, Matsuoka M. Natural history of adult T-cell leukemia/lymphoma and approaches to therapy. Oncogene 24: 6047-6057, 2005. 